\title{
Zinc Improves Biocontrol of Fusarium Crown and Root Rot of Tomato by Pseudomonas fluorescens and Represses the Production of Pathogen Metabolites Inhibitory to Bacterial Antibiotic Biosynthesis
}

\author{
Brion K. Duffy and Geneviève Défago
}

Phytopathology Group, Institute for Plant Sciences, Swiss Federal Institute of Technology, Universitätstrasse 2, CH-8092, Zürich. Accepted for publication 9 September 1997.

\begin{abstract}
Duffy, B. K., and Défago, G. 1997. Zinc improves biocontrol of Fusarium crown and root rot of tomato by Pseudomonas fluorescens and represses the production of pathogen metabolites inhibitory to bacterial antibiotic biosynthesis. Phytopathology 87:1250-1257.

Crown and root rot of tomato caused by Fusarium oxysporum f. sp. radicis-lycopersici is an increasing problem in Europe, Israel, Japan, and North America. The biocontrol agent Pseudomonas fluorescens strain CHA0 provides only moderate control of this disease. A one-time amendment of zinc EDTA at $33 \mu \mathrm{g}$ of $\mathrm{Zn}^{2+} / \mathrm{ml}$ to hydroponic nutrient solution in soilless rockwool culture did not reduce disease when used alone, but did reduce disease by $25 \%$ in the presence of CHA0. In in vitro studies with the pathogen, zinc at concentrations as low as $10 \mu \mathrm{g} / \mathrm{ml}$ abolished production of the phytotoxin fusaric acid, a Fusarium pathogenicity factor, and increased production of microconidia over 100 -fold, but reduced total biomass. Copper EDTA at $33 \mu \mathrm{g}$ of $\mathrm{Cu}^{2+} / \mathrm{ml}$ had a similar effect as zinc on the

acid. Fusaric acid at concentrations as low as $0.12 \mu \mathrm{g} / \mathrm{ml}$ repressed production by CHA0 of the antibiotic 2,4-diacetylphloroglucinol, a key factor in the biocontrol activity of this strain. Production of pyoluteorin by CHA0 was also reduced, but production of hydrogen cyanide and protease was not affected, suggesting that fusaric acid affects biosynthesis at a regulatory level downstream of gacA and apdA genes. Fusaric acid did not affect the recovery of preformed antibiotics nor did it affect bacterial growth even at concentrations as high as $200 \mu \mathrm{g} / \mathrm{ml}$. When microbial metabolite production was measured in the rockwool bioassay, zinc amendments reduced fusaric acid production and enhanced 2,4-diacetylphloroglucinol production. We suggest that zinc, which did not alleviate the repression of antibiotic biosynthesis by fusaric acid, improved biocontrol activity by reducing fusaric acid production by the pathogen, which resulted in increased antibiotic production by the biocontrol agent. This demonstrates that pathogens can have a direct negative impact on the mechanism(s) of biocontrol agents.
\end{abstract} pathogen in vitro; it reduced disease when used alone, and increased the biocontrol activity of $\mathrm{CHA} 0$ in soilless culture. Ammonium-molybdate neither improved the biocontrol activity of $\mathrm{CHA} 0$ nor affected production of fusaric acid or microconidia. Strain CHAO did not degrade fusaric
Additional keywords: Lycopersicum esculentum, metal ions, plant growthpromoting rhizobacteria, soilborne pathogen, trace minerals.
Micro- and macroelement amendments have been used commercially on a limited scale to manage certain soilborne diseases including Fusarium wilt of tomato and other vegetable crops (16). Disease reduction is most often attributed to improved nutrition that boosts host defenses or to direct inhibition of fungal growth and activity. Pathogen suppression may also result indirectly from amendment-mediated modification of chemical and physical properties like soil and rhizosphere $\mathrm{pH}$ (35) or from modification of host root exudates to disfavor pathogenic activity (18). In a few cases, though, mineral amendments appear to reduce disease by indirectly stimulating indigenous populations of microorganisms that are beneficial to plant growth and antagonistic to pathogens (18). For example, broadcast application of $\mathrm{NaCl}$, which has traditionally been used to manage Fusarium on asparagus, favors populations of manganese-reducing bacteria in the rhizosphere that increase availability of this essential trace mineral to the plant and may evince a fungistatic effect on the pathogen (15). While exploitation of indigenous microbial communities is an ecologically sound approach to achieve sustainable disease control and deserves greater attention, this approach relies on germinal populations that may not be present in all soils. It also may require several growing seasons to obtain economic control and may not be compatible with all cropping systems.

Corresponding author: B. K. Duffy; E-mail address: brion.duffy@ipw.agrl.ethz.ch

Publication no. P-1997-1020-01R

(C) 1997 The American Phytopathological Society
There is increasing interest in the introduction of bacterial and fungal biocontrol agents for managing soilborne pathogens, partly as a response to public concerns about nontarget effects of synthetic pesticides and fumigants, but also because of a lack of effective controls for soilborne pathogens (8). However, many biocontrol agents are inconsistent in their performance from site to site, and this has been a primary obstacle to commercial development (44). Soil chemical and physical properties have been implicated in the variable biocontrol activity of Pseudomonas fluorescens strain 2-79 and Trichoderma koningii against take-all on wheat $(13,44)$, and results indicate that introduced biocontrol agents and indigenous populations of antagonistic microbes are influenced by some of the same abiotic soil conditions. While effects of $\mathrm{pH}$ and, to a lesser extent, clay type, organic matter content, and organic amendments on biocontrol agents have been reported $(27,37,38,40,41)$, the influence of minerals on suppression of soilborne pathogens has received little attention, and the potential for utilizing mineral amendments for optimizing biocontrol remains largely unexplored.

P. fluorescens strain CHA0 was isolated from roots of tobacco grown in soil that is naturally suppressive of black root rot caused by Chalara elegans (synanamorph Thielaviopsis basicola) (40). Application of CHA0 to seed- or plant-growth medium suppresses this and a variety of other soilborne fungal diseases, but the level of control can depend on the predominant type of clay mineral and on the pathogen and host plant (40). The primary mechanism of biocontrol for most diseases is the production of the antimicrobial compounds 2,4-diacetylphloroglucinol (PHL), pyoluteorin (PLT), and hydrogen cyanide (40). In addition, strain CHA0 produces 
several high-affinity, metal-chelating siderophores (i.e., pyoverdine, pyochelin, and salicylic acid) that may contribute to nutrient competition with pathogens and to systemic acquired host resistance (40). Recently, we found that in vitro production of PHL and PLT is stimulated by zinc and production of salicylic acid is stimulated by molybdenum and magnesium (12), while iron availability is critical for hydrogen cyanide production (40).

In this study, we evaluated the effect of trace mineral amendments on the biocontrol activity of CHA0. We selected crown and root rot of tomato caused by Fusarium oxysporum Schlechtend.:Fr. f. sp. radicis-lycopersici W.R. Jarvis \& Shoemaker as our model pathosystem, because this disease is an increasingly important disease in commercial tomato production in Europe, North America, Japan, and Israel and losses are especially severe at the seedling stage in soilbed and hydroponic culture (26). Studies were conducted in a rockwool soilless system, because it is more amenable than soil to management of nutrient supply and it is the predominant method for tomato production in Europe. Our objectives were to (i) determine the influence of zinc, copper, and ammoniummolybdate amendments on crown and root rot of tomato and the biocontrol activity of $\mathrm{CHA} 0$ against this disease; and (ii) elucidate possible mechanisms of action by which the minerals influence the interaction between the pathogen and the biocontrol agent.

\section{MATERIALS AND METHODS}

Microorganisms and inoculum production. $F$. oxysporum $\mathrm{f}$. sp. radicis-lycopersici strain 22 (a gift of C. Alabouvette, INRA, Dijon, France) was reisolated from infected tomato plants and stored on $2 \%$ malt agar at $3{ }^{\circ} \mathrm{C}$ and in $2 \%$ malt broth (pH 5.5) plus $40 \%$ glycerol at $-80^{\circ} \mathrm{C}$. Starter cultures of malt broth $(150 \mathrm{ml}$ per $500-\mathrm{ml}$ Erlenmeyer flask with one baffle; A. Dumas AG, Zürich) were inoculated with six 4-mm agar plugs taken from a fresh malt agar culture of $F$. oxysporum f. sp. radicis-lycopersici. Inoculum of $F$. oxysporum f. sp. radicis-lycopersici was produced by inoculating malt broth with $1 \mathrm{ml}$ of a starter culture. Cultures were incubated 10 to 14 days at $24^{\circ} \mathrm{C}$ on a rotary shaker $(150 \mathrm{rpm})$. Fungal biomass (mycelia and microconidia) was collected by centrifugation at 4,000 $\operatorname{rpm}(2,200 \times g)$ for $15 \mathrm{~min}$, and then briefly homogenized in a blender.

Wild-type CHA0, spontaneous rifampicin-resistant derivative $\mathrm{CHAO}^{\text {rif }}$, and antibiotic-overproducing derivative CHA0/pME3424 (34) were stored in Luria-Bertani broth (LB) plus $40 \%$ glycerol at $-80^{\circ} \mathrm{C}$. Wild-type $\mathrm{CHA} 0$ and the rifampicin-resistant derivative were similar for growth in LB, carbon source utilization (Biolog, Hayward, CA), production of PHL and PLT, and inhibition of $F$. oxysporum f. sp. radicis-lycopersici growth in vitro. Inoculum of CHA0 was produced in $150 \mathrm{ml}$ of LB in 500-ml Erlenmeyer flasks incubated for $24 \mathrm{~h}$ at $27^{\circ} \mathrm{C}$ on a rotary shaker $(140 \mathrm{rpm})$. Bacteria were collected by centrifugation, washed once with sterile double-distilled water, and brought to a concentration of approximately $10^{9} \mathrm{CFU}$ per $\mathrm{ml}$.

Influence of trace mineral amendments on disease suppression in rockwool soilless culture. Tomato seeds (Lycopersicum esculentum Mill. 'Bonnie Best'; a gift of Peptoseed Co., Saticoy, CA) were surface-disinfested for $30 \mathrm{~min}$ in $1 \%$ sodium hypochlorite and pregerminated for 48 to $72 \mathrm{~h}$ on $0.85 \%$ water agar at $24^{\circ} \mathrm{C}$ in darkness. Seeds with radicles 2 to $4 \mathrm{~mm}$ long were placed in the indentations of rockwool cubes $\left(3.5 \mathrm{~cm}^{2}\right.$ diameter $\times 4 \mathrm{~cm}$ deep, one seed per cube; Grodania A/S, Hedehusene, Denmark) with 18 cubes per plastic tray $(23.5 \times 28.5 \mathrm{~cm}$ diameter $\times 5.5 \mathrm{~cm}$ deep $)$. The rockwool was saturated with 1 liter of a nutrient solution designed for commercial hydroponic tomato production by the Office of Horticultural Production of Geneva, Switzerland, and was composed of $\mathrm{Ca}\left(\mathrm{NO}_{3}\right)_{2} \cdot 4 \mathrm{H}_{2} \mathrm{O}(955.5 \mathrm{mg} /$ liter $), \mathrm{NH}_{4} \mathrm{H}_{2} \mathrm{PO}_{4}(660 \mathrm{mg} /$ liter), $\mathrm{KNO}_{3}$ (450 mg/liter), $\mathrm{MgSO}_{4} \cdot 7 \mathrm{H}_{2} \mathrm{O}$ (360 mg/liter), $\mathrm{K}_{2} \mathrm{SO}_{4}$ (174 mg/liter), $\mathrm{KH}_{2} \mathrm{PO}_{4}$ (78 mg/liter), Fe-EDDHA (ethylenediaminedi-o-hydroxyphenylacetic acid; $25 \mathrm{mg} / \mathrm{liter}$ ), EDDHA (4 mg/liter),
$\mathrm{Na}_{2} \mathrm{~B}_{4} \mathrm{O}_{7} \cdot 10 \mathrm{H}_{2} \mathrm{O}(1.05 \mathrm{mg} /$ liter $), \mathrm{MnSO}_{4} \cdot 7 \mathrm{H}_{2} \mathrm{O}(1.02 \mathrm{mg} /$ liter $)$, $\mathrm{ZnSO}_{4} \cdot 7 \mathrm{H}_{2} \mathrm{O}(0.43 \mathrm{mg} / \mathrm{liter}), \mathrm{CuSO}_{4} \cdot 5 \mathrm{H}_{2} \mathrm{O}(0.2 \mathrm{mg} / \mathrm{liter})$, and $\mathrm{Na}_{2} \mathrm{MoO}_{4} \cdot 2 \mathrm{H}_{2} \mathrm{O}(0.04 \mathrm{mg} / \mathrm{liter})$. Prior to saturating the rockwool, the nutrient solution was inoculated with $\mathrm{CHA} 0$ at approximately $2 \times 10^{7} \mathrm{CFU}$ per ml, F. oxysporum f. sp. radicis-lycopersici at approximately $4 \times 10^{6}$ microconidia plus mycelial fragments per $\mathrm{ml}$, or both. Filter-sterilized stock solutions of minerals were added to give concentrations of $33 \mu \mathrm{g} / \mathrm{ml}$ of $\mathrm{Zn}^{2+}$ (as EDTA disodium salt, $\mathrm{Zn} \mathrm{C}_{10} \mathrm{H}_{12} \mathrm{~N}_{2} \mathrm{Na}_{2} \mathrm{O}_{8} \cdot 4 \mathrm{H}_{2} \mathrm{O}$ ), $\mathrm{Cu}^{2+}$ (as EDTA disodium salt, $\mathrm{Cu}$ $\left.\mathrm{C}_{10} \mathrm{H}_{12} \mathrm{~N}_{2} \mathrm{Na}_{2} \mathrm{O}_{8}\right)$, or $\mathrm{Mo}_{7}\left(\mathrm{NH}_{4}\right)_{6} \mathrm{O}_{24} \cdot 4 \mathrm{H}_{2} \mathrm{O}$. A mineral mix was prepared with one-third the concentration of each compound. Plants were grown in a growth chamber with $16 \mathrm{~h}$ of light and $8 \mathrm{~h}$ of darkness, $22^{\circ} \mathrm{C}$ 'day' and $18^{\circ} \mathrm{C}$ 'night', and $70 \%$ relative humidity. After 7 days, approximately $400 \mathrm{ml}$ of nutrient solution (without additional mineral, bacterial, or pathogen treatment) was added to each tray; subsequently, Millipore-filtered double-distilled water was added as needed to maintain a solution level of 1 to $2 \mathrm{~cm}$. Fourteen to sixteen days after planting, tomato seedlings were carefully removed from the rockwool with the upper $1.5 \mathrm{~cm}$ of the root system attached. Fresh plant weight was measured, and disease severity was rated on a scale of 0 to 4 in which $0=$ symptomless, 1 = slight brown discoloration of the upper root system, $2=$ moderate brown discoloration of two-thirds or less of the upper root system, 3 = extreme brown discoloration of the upper root system and numerous necrotic lesions extending up the crown and stem, and $4=$ seedling dead or nearly so (26). A representative sample of brown tissue was plated onto Komada's medium (22) to confirm F. oxysporum f. sp. radicis-lycopersici as the causal agent. Treatments consisted of 18 plants and were replicated four times. Treatments were arranged as a $5 \times 3$ factorial in a split-plot design with a main plot of mineral treatment (none, zinc, copper, ammonium-molybdate, and mineral mix) and a subplot of biocontrol treatment (no microbial inoculants, F. oxysporum f. sp. radicis-lycopersici alone, and $F$. oxysporum $\mathrm{f}$. sp. radicis-lycopersici plus CHA0).

Influence of minerals on pathogen growth, production of microconidia, and fusaric acid (FA) production. Czapek-Dox medium (Oxoid, Hampshire, United Kingdom) (20 ml in 100-ml flasks with one baffle) amended with a range of mineral concentrations was inoculated with $10 \mu \mathrm{l}$ of a F. oxysporum f. sp. radicislycopersici starting culture to give approximately 10 to 100 microconidia per $\mathrm{ml}$ and incubated for 8 days at $24^{\circ} \mathrm{C}$ on a rotary shaker (120 rpm). Numbers of microconidia were determined using a haemocytometer, and cultures were centrifuged to collect total fungal biomass (mycelia plus microconidia) for dry weight determination after lyophilization. The supernatant was acidified to $\mathrm{pH} 2$ with $2 \mathrm{~N} \mathrm{HCl}$, mixed with $20 \mathrm{ml}$ of ethylacetate, and shaken for $30 \mathrm{~min}$ at 200 $\mathrm{rpm}$. The solvent phase was separated with centrifugation at 4,500 rpm $(2,790 \times g)($ GP centrifuge; Beckman Instruments, Palo Alto, CA) for $10 \mathrm{~min}$ and flash-evaporated (Rotovapor RE120; Büchi Labortechnik AG, Flawil, Switzerland). The residue was resuspended in $1 \mathrm{ml}$ of methanol and analyzed with high-performance liquid chromatography (HPLC) using a Hewlett Packard 1090 liquid chromatograph (Hewlett-Packard Co., Palo Alto, CA) equipped with a reverse-phase column $(4 \times 100 \mathrm{~mm})$ packed with Nucleosil 120-5-C18 (Macherey-Nagel, Oensingen, Switzerland) and thermostatically controlled at $50^{\circ} \mathrm{C}$. Samples of $10 \mu \mathrm{l}$ were eluted at a flow rate of $1 \mathrm{ml} / \mathrm{min}$ with a three-step linear gradient of methanol in $o$-phosphoric acid. FA was detected with an ultraviolet diodearray detector at $270 \mathrm{~nm}$ at a retention time of approximately $5.1 \mathrm{~min}$ and quantified against a standard curve of synthetic FA (molecular weight of 179.2; Sigma Chemical Co., St. Louis). The efficiency of recovery for this extraction method was approximately $60 \%$ for synthetic FA added to media and incubated for 2 days. Treatments were arranged in separate randomized complete blocks for each mineral (zinc, copper, ammonium-molybdate, and mineral mix) at four concentrations of $0,10,33$, and $100 \mu \mathrm{g} / \mathrm{ml}$. Each treatment consisted of four replicate flasks per trial. 
Influence of FA on bacterial growth and secondary metabolism. The relationship between FA concentration and repression of PHL and monoacetylphloroglucinol was observed by inoculating $10 \mu \mathrm{l}$ of an overnight LB culture of CHA0 $\left(10^{9} \mathrm{CFU}\right.$ per ml) into 100 -ml wide-mouth Erlenmeyer flasks (sealed with 3.5-cm-diameter cotton plugs) containing $20 \mathrm{ml}$ of PCG liquid medium (10 g of Bacto-Peptone, $1 \mathrm{~g}$ of Casamino Acids, $10 \mathrm{~g}$ of glucose, and 1 liter of double-distilled water, $\mathrm{pH} 6.5$ after autoclaving) (39) amended with FA at $0,0.01,0.04,0.12,0.37,1.1,3.3,10,100$, and $200 \mu \mathrm{g} / \mathrm{ml}$. A fresh stock solution of synthetic FA was prepared immediately prior to use by dissolving $200 \mathrm{mg}$ of FA in $1.5 \mathrm{ml}$ of methanol, bringing to a volume of $8 \mathrm{ml}$ with sterile doubledistilled water, adjusting the $\mathrm{pH}$ to 6.5 with a few drops of $2 \mathrm{~N}$ $\mathrm{NaOH}$, and sterilizing through a $2-\mu \mathrm{m}$ filter. Production of PHL by CHA0 was observed in PCG medium. Cultures were incubated for $48 \mathrm{~h}$ at $27^{\circ} \mathrm{C}$ on a rotary shaker $(140 \mathrm{rpm})$, and culture $\mathrm{pH}$ was measured and bacterial growth determined by spreading appropriate dilutions onto King's medium B agar. Cultures then were acidified to $\mathrm{pH} 2$ with $2 \mathrm{~N} \mathrm{HCl}$ and extracted with $20 \mathrm{ml}$ of ethylacetate. Concentrations of PHL (molecular weight of 210 and retention time of $11.6 \mathrm{~min}$ ) and monoacetylphloroglucinol (molecular weight of 186 and retention time of $6.2 \mathrm{~min}$ ) were determined with HPLC analysis with maximum detection at 270 and $290 \mathrm{~nm}$, respectively (20). Effects of zinc $\left(65 \mu \mathrm{g} / \mathrm{ml}\right.$ of $\mathrm{Zn}^{2+}$ as $\left.\mathrm{ZnSO}_{4} \cdot 7 \mathrm{H}_{2} \mathrm{O}\right)$ on PHL production by $\mathrm{CHA} 0$, zinc on FA-mediated repression of antibiotic production, and FA $(100 \mu \mathrm{g} / \mathrm{ml})$ on production of PHL by the antibiotic-overproducing derivative CHA0/pME3424 (34) were tested in PCG medium. Production of hydrogen cyanide was estimated with indicator paper (41) after $24 \mathrm{~h}$ of growth in GNB media (8 g of Difco nutrient broth [Difco Laboratories, Detroit], $4 \mathrm{~g}$ of Difco

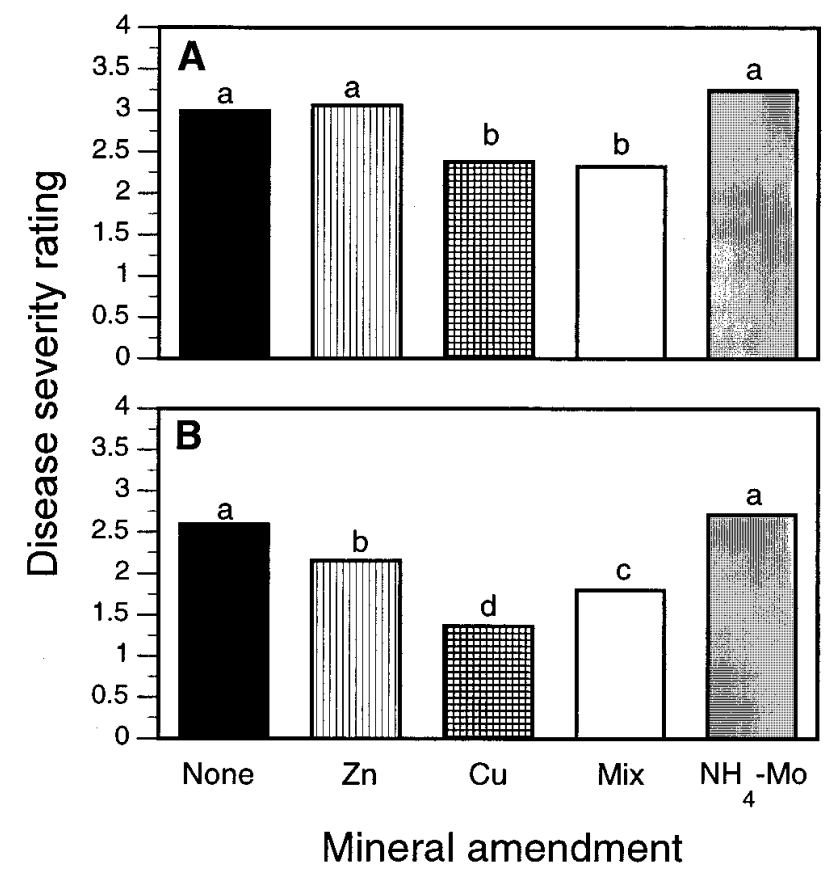

Fig. 1. Effect of mineral amendments on A, tomato crown and root rot disease severity caused by Fusarium oxysporum f. sp. radicis-lycopersici; and B, disease suppression by Pseudomonas fluorescens CHA0. One-time mineral amendments to nutrient solution at $33 \mu \mathrm{g} / \mathrm{ml}$ included zinc ( $\mathrm{Zn}$ ) or copper $(\mathrm{Cu})$ (as EDTA complex), ammonium molybdate $\left(\mathrm{NH}_{4}-\mathrm{Mo}\right)$, or a mix of $1 / 3$ each. Control plants (none) received only nutrient solution. Tomato plants were grown in soilless rockwool culture infested with $F$. oxysporum f. sp. radicis-lycopersici for 2 weeks and evaluated for disease severity on a scale of 0 to 4 in which $0=$ symptomless and $4=$ dead or nearly so. Values represent the mean of eight replications. Bars with the same letter are not significantly different according to Fisher's protected $(P=0.05)$ least significant difference (LSD) test. LSD values were A, 0.28 and B, 0.33. For all mineral treatments, CHA0 significantly reduced disease severity rating compared with the mineral treatment used alone (comparisons not shown).
Bacto-gelatine, $4 \mathrm{~g}$ of $\mathrm{NaCl}$, and 1 liter of double-distilled water, pH 6.7 after autoclaving) amended with $100 \mu \mathrm{g} / \mathrm{ml}$ of FA. Production of PLT (molecular weight of 268 and retention time of $9.4 \mathrm{~min}$ ), pyochelin (molecular weight of 325 and retention times for characteristic double peaks of 10.1 and $10.8 \mathrm{~min}$ ), and salicylic acid (molecular weight of 138 and retention time of $8.2 \mathrm{~min}$ ) after 2 days of growth in GNB media was quantified with HPLC analysis at 313,254 , and $300 \mathrm{~nm}$, respectively, against standard curves of reference compounds. Production of extracellular protease was determined after 5 days of growth in GNB media with the azocasein reaction (33). Treatments were arranged in a randomized complete block design with three replicate broths per trial. Degradation of FA by CHA0 was measured by HPLC analysis of extractions of 48-h PCG and GNB cultures with and without $100 \mu \mathrm{g} / \mathrm{ml}$ of FA.

Influence of FA on the recovery of preformed antibiotic. To determine whether the reduction in PHL accumulation in treatments amended with FA were due to complexing of the antibiotic or to other alterations interfering with antibiotic recovery rather than inhibition of biosynthesis, a 300-ml culture of CHA0 grown $48 \mathrm{~h}$ in PCG media was partitioned into three aliquots of $100 \mathrm{ml}$ each. One aliquot was extracted and analyzed with HPLC to determine the concentration of PHL in the culture. The other two aliquots were amended with 100 and $500 \mu \mathrm{g} / \mathrm{ml}$ of synthetic FA and shaken for $4 \mathrm{~h}$ at $27^{\circ} \mathrm{C}$, and then extracted and analyzed by HPLC to determine the concentration of PHL. Each treatment consisted of three replicate cultures.

Metabolite production in the rockwool bioassay. Tomato plants were grown in rockwool, and $F$. oxysporum f. sp. radicis-lycopersici, $\mathrm{CHA}^{\text {rif }}$, and Zn-EDTA were added to nutrient solution as described above. After 2 to 3 weeks, tomato shoots were removed and the rockwool with roots from two trays of 42 plants each was mashed by hand in a wide-mouth, 5-liter glass flask. Appropriate dilutions of the suspension were spread onto Komada's agar and onto King's B agar plus $100 \mu \mathrm{g} / \mathrm{ml}$ of cycloheximide and rifampicin to estimate numbers of $F$. oxysporum f. sp. radicis-lycopersici and $\mathrm{CHAO}^{\text {rif }}$, respectively. The rockwool and nutrient solution mixture was acidified to $\mathrm{pH} 2.5$ with $2 \mathrm{~N} \mathrm{HCl}$, and then extracted by agitating the rockwool mush by hand with 2.5 liters of ethylacetate for two periods of 5 to $10 \mathrm{~min}$ with a 1- to 2-h stationary period at $3^{\circ} \mathrm{C}$ between the periods. After extraction, the rockwool was discarded and the organic phase was transferred to a graduated cylinder and kept overnight at $2^{\circ} \mathrm{C}$ in darkness. Four aliquots of $250 \mathrm{ml}$ each were flash-evaporated, and the combined residues were concentrated in $1 \mathrm{ml}$ of methanol. Extracts were kept at $-20^{\circ} \mathrm{C}$ for 2 to 5 days, and then centrifuged to remove precipitates. Samples were analyzed with HPLC using a $4 \times 250$-mm reverse-phase column (Macherey-Nagel). The recovery efficiencies for this procedure were approximately $30 \%$ for PHL and $45 \%$ for FA, estimated by adding reference compounds to rockwool with tomato plants and nutrient solution. Using this longer column, retention times for reference compounds were approximately 22.5 min for PHL and $9.5 \mathrm{~min}$ for FA. Detection limits were approximately $0.07 \mu \mathrm{g}$ per plant for PHL and $0.45 \mu \mathrm{g}$ per plant for FA with a $10-\mu \mathrm{l}$ injection volume. For each extraction, two trays of tomato (84 plants total) per treatment were used. Three separate extractions were made to estimate metabolite production.

Statistical analysis. All experiments were repeated, and data from two or three trials were pooled for final analysis after confirming homogeneity of variances with an $F$ test, after finding no significant treatment $x$ trial interaction in a preliminary analysis of variance, or both. Main effects and interactions were analyzed for significance with the SAS general linear models procedure (release 6.08; SAS Institute, Cary, NC), and means were compared using Fisher's protected $(P \leq 0.05)$ least significant difference test when appropriate. Relationships between minerals and pathogen growth, and between FA concentration and antibiotic production by $\mathrm{CHA} 0$, were analyzed using the SAS regression procedure (Pear- 
son option) after log transformation to normalize the data. Microbial CFU data were normalized with the $\log _{10}+1$ transformation prior to analysis. For the in situ metabolite production experiment, metabolite concentration data are presented with ranges from three separate extractions. Within a microbial treatment, the effect of zinc amendment on metabolite production and microbial CFU was determined using Student's $t$ test.

\section{RESULTS}

Effect of mineral amendments on Fusarium crown and root rot of tomato and on disease suppression by CHA0. Introduction of F. oxysporum f. sp. radicis-lycopersici into rockwool seeded with tomato resulted in severe crown and root rot (disease rating of 3 on a scale of 0 to 4) (Fig. 1) and a 50\% reduction of plant fresh weight (Fig. 2) $(P=0.0001)$. The pathogen was recovered from all lesions plated onto Komada's selective medium. The main effects of mineral and biocontrol treatment and the interaction had a significant influence on disease severity rating $(P=0.0001)$ and on fresh plant weight $(P \leq 0.0132)$. Data were further analyzed based on the response to each main effect, and significant differences were observed among biocontrol treatments by each mineral treatment and among mineral treatments by each biocontrol treatment. Figures represent comparisons of mineral treatments by biocontrol treatment.

In the presence of $F$. oxysporum f. sp. radicis-lycopersici, CHA0 alone provided a moderate level of protection, reducing disease severity from a rating of 3 to 2.5 (Fig. 1$)(P=0.0001)$. In fact, combination of CHA0 with any mineral treatment (Fig. 1B) significantly reduced disease severity compared with the minerals alone (Fig. 1A, comparisons not shown). However, combination of CHA0 with individual mineral treatments (Fig. 2C) did not significantly increase plant fresh weight compared with the same mineral used alone (Fig. 2B), except in the case of zinc, when CHA0 treatment increased plant weight $(P=0.0001$, comparisons not shown). When the minerals were used alone (plants inoculated with the pathogen but not the biocontrol agent), both copper and the mineral mix reduced the disease severity rating from 3 to 2.4 (Fig. 1A) and significantly increased plant weight from 163 to $217 \mathrm{mg}$ compared with no mineral treatment (Fig. 2B) $(P \leq 0.0002)$.

Minerals had a significant influence on the biocontrol activity of CHA0. When data were analyzed to compare the effect of minerals on plants inoculated with both the pathogen and the biocontrol agent, combinations of CHA0 with all of the mineral treatments except ammonium-molybdate significantly reduced disease as compared with CHA0 used alone (Fig. 1B) $(P=0.0001)$. Combinations of $\mathrm{CHA} 0$ with copper and the mineral mix significantly increased plant fresh weight compared with $\mathrm{CHA} 0$ used alone (Fig. 2C) $(P \leq 0.0004)$.

Small lesions developed on a few plants not inoculated with $F$. oxysporum f. sp. radicis-lycopersici, possibly resulting from aerial dissemination of micro- and macroconidia from stem lesions in treatments with $F$. oxysporum f. sp. radicis-lycopersici. There was no significant difference in chance infection between the absolute control (no F. oxysporum f. sp. radicis-lycopersici, no CHA0, and no minerals, rating 0.03 ) and any of the controls with minerals (ratings ranging from 0.01 for the mineral mix to 0.06 for the ammonium-molybdate). In the absence of pathogen and biocontrol agent, none of the minerals at the concentrations shown in this study had a significant effect on plant growth (Fig. 2A). Higher concentrations (66 and $100 \mu \mathrm{g} / \mathrm{ml}$ ) of ammonium-molybdate and the mineral mix did have slight phytotoxic effects on tomato growth in preliminary tests (data not shown).

Effect of minerals on pathogen growth, production of microconidia, and FA production. Minerals had a differential effect on the pathogen. Zinc, copper, and the mineral mix increased the number of microconidia $\left(P \leq 0.002 ; r^{2}=0.23,0.44\right.$, and 0.31 , respectively) (Fig. 3A) and the total fungal biomass $\left(P \leq 0.007 ; r^{2}=\right.$
$0.42,0.57$, and 0.32 , respectively) (Fig. 3B). FA production was almost completely repressed by zinc, copper, and the mineral mix at concentrations as low as $10 \mu \mathrm{g} / \mathrm{ml}\left(P \leq 0.001 ; r^{2}=0.35,0.57\right.$, and 0.36 , respectively) (Fig. $3 \mathrm{C}$ ). In contrast, ammonium-molybdate did not have a significant effect on production of microconidia, total fungal biomass, or FA production (Fig. 3). Recovery of FA produced by $F$. oxysporum f. sp. radicis-lycopersici or synthetic FA was not affected by zinc or ammonium-molybdate at the highest mineral concentration tested $(100 \mu \mathrm{g} / \mathrm{ml})$ compared with treatments without minerals, but recovery of FA was reduced 5 to $10 \%$ by copper amendment.

Effect of FA on CHA0 secondary metabolism. Synthetic FA at concentrations of $0.37 \mu \mathrm{g} / \mathrm{ml}$ or greater completely suppressed production of both PHL $\left(P=0.02, r^{2}=0.87\right)$ and monoacetylphloroglucinol $\left(P=0.09, r^{2}=0.65\right)$ by CHA0 in PCG medium (Fig. 4). FA at $100 \mu \mathrm{g} / \mathrm{ml}$ completely suppressed PHL production by the overproducing derivative CHA0/pME3424, which produced five to six times more PHL than the wild type in the absence of FA (Table 1). Production of PLT by CHA0 in GNB medium was reduced approximately $50 \%$ by $100 \mu \mathrm{g} / \mathrm{ml}$ of FA (Table 1). FA did
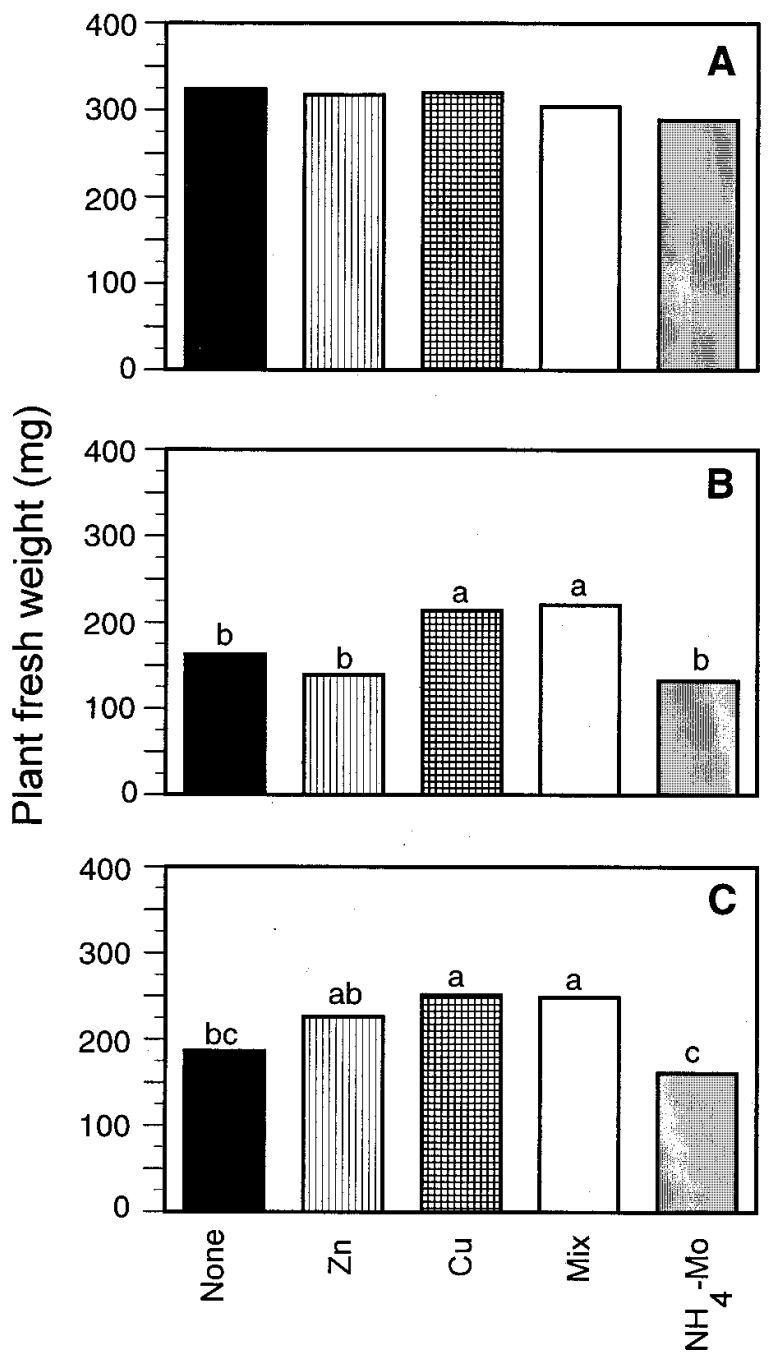

Mineral amendment

Fig. 2. Effect of mineral amendments on fresh weight of tomato plants A, grown in nutrient solution without pathogen or biocontrol agent; B, challenged with Fusarium oxysporum f. sp. radicis-lycopersici (no biocontrol agent); and C, protected with Pseudomonas fluorescens strain CHA0. Figure 1 describes the experimental procedure. In the absence of the pathogen $\mathbf{A}$, mineral amendments had no effect on plant fresh weight and means were not compared using Fisher's protected least significant difference (LSD) test. For treatments with the pathogen, LSD values were $\mathbf{B}, 42.7$ and $\mathbf{C}, 44.3$. 
not affect the production of other secondary metabolites that are regulated by gacA and apdA genes including hydrogen cyanide and extracellular proteases (Table 1) $(33,40)$. FA reduced the production of the pyochelin siderophore, but increased slightly the production of salicylic acid, a precursor for pyochelin (Table 1). Inhibition of antibiotic and pyochelin production by FA was not reversed by the addition of $\mathrm{Zn}^{2+}$ at $66 \mu \mathrm{g} / \mathrm{ml}$ (Table 1).

FA at $200 \mu \mathrm{g} / \mathrm{ml}$ or less had no effect on the $\mathrm{pH}$ of PCG or GNB media at the start or end of the experiment (approximately $\mathrm{pH} 6.5$ and 8.1 , respectively), nor was bacterial growth affected (5 to $8 \times$ $10^{7}$ CFU per $\mathrm{ml}$ in treatments with and without FA). In PCG or GNB medium, CHA0 neither degraded nor interfered with the recovery of FA ( $60 \%$ recovery with or without $\mathrm{CHA} 0$ after 2 days of incubation). Likewise, addition of synthetic FA to 48-h PCG cultures of CHA0 had no effect on the recovery of preformed PHL. The antibiotic was recovered at $0.75 \pm 0.2(\mu \mathrm{g} / \mathrm{ml} \pm$ standard error of the mean) without FA, $0.79 \pm 0.1$ with $100 \mu \mathrm{g} / \mathrm{ml}$ of FA, and $0.76 \pm 0.2$ with $500 \mu \mathrm{g} / \mathrm{ml}$ of FA.

Effect of zinc amendments on in situ metabolite production by the pathogen and biocontrol agent. Extracts from the rockwool assay contained compounds that comigrated with and had ultraviolet spectra identical to FA and PHL. In the absence of zinc, FA was detected in F. oxysporum f. sp. radicis-lycopersici and $F$. oxysporum f. $\mathrm{sp}$. radicis-lycopersici plus $\mathrm{CHA} 0^{\text {rif }}$ treatments at concentrations of 5.1 and $5.7 \mu \mathrm{g}$ per plant, respectively (Table 2). In the presence of zinc, FA was not detected in two of three trials
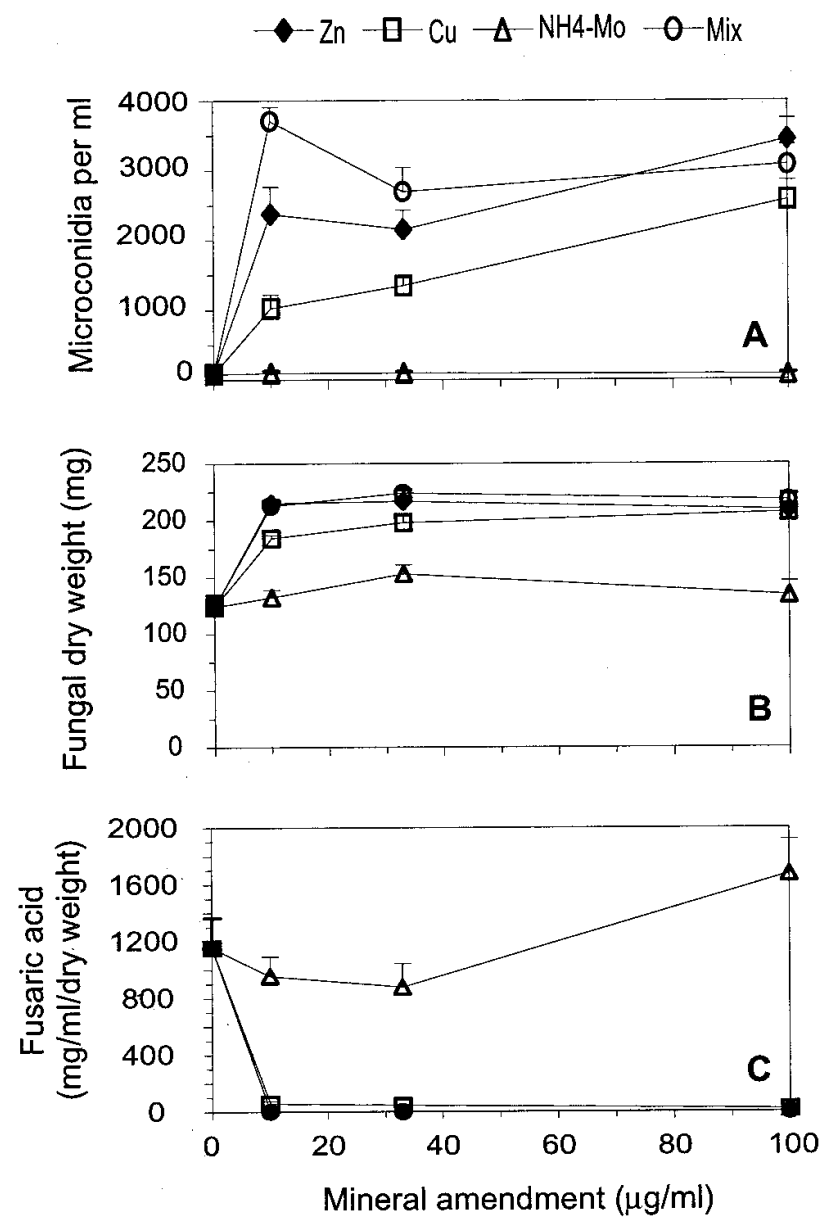

Fig. 3. Effect of mineral amendments (0 to $100 \mu \mathrm{g} / \mathrm{ml}$ for zinc and copper as EDTA salts, ammonium molybdate, and a mix of $1 / 3$ each) to Czapek-Dox broth on $\mathbf{A}$, fungal production of microconidia; $\mathbf{B}$, fungal growth; and $\mathbf{C}$, fusaric acid production. Fusarium oxysporum f. sp. radicis-lycopersici was incubated for 8 days $\left(24^{\circ} \mathrm{C}, 120 \mathrm{rpm}\right)$. Fusaric acid was quantified with highperformance liquid chromatography and expressed relative to biomass (mycelia and microconidia). Vertical bars indicate standard error of the mean. when F. oxysporum f. sp. radicis-lycopersici was inoculated alone, and it was never detected when $F$. oxysporum f. sp. radicis-lycopersici was coinoculated with $\mathrm{CHA} 0^{\text {rif. }}$. In the absence of zinc, PHL was detected in the CHA0 $0^{\text {rif }}$ treatment at a concentration of $0.29 \mu \mathrm{g}$ per plant, but it was not detected when $\mathrm{CHA} 0^{\text {rif }}$ was coinoculated with $F$. oxysporum f. sp. radicis-lycopersici. When CHA0 was tested alone and zinc was added to nutrient solution, $0.39 \mu \mathrm{g}$ of PHL per plant was detected; $0.48 \mu \mathrm{g}$ of PHL per plant was detected when $\mathrm{CHA}^{\text {rif }}$ was coinoculated with $F$. oxysporum $\mathrm{f}$. sp. radicis-lycopersici. Neither PHL nor FA were detected in extracts of the control treatments.

Zinc amendment had no effect on the population size of $\mathrm{CHA} 0^{\text {rif }}$ when the biocontrol agent was tested alone, but it slightly increased the population size of $\mathrm{CHA}^{\text {rif }}$ when it was coinoculated with $F$. oxysporum f. sp. radicis-lycopersici (Table 2). In contrast, while zinc had no effect on the population size of $F$. oxysporum f. sp. radicis-lycopersici when the pathogen was tested alone, zinc reduced the population size of $F$. oxysporum $\mathrm{f}$. sp. radicis-lycopersici when it was coinoculated with $\mathrm{CHAO}^{\text {rif }}$. This suggests that zinc had a positive effect on the competitiveness of $\mathrm{CHA}^{\mathrm{rif}}$ and a negative effect on the competitiveness of $F$. oxysporum f. sp. radicis-lycopersici.

\section{DISCUSSION}

P. fluorescens $\mathrm{CHA0}$ is a biocontrol agent with activity against diseases caused by several soilborne fungal pathogens (40). Against Fusarium crown and root rot of tomato, however, CHA0 was only moderately effective. In our screening program using this disease assay to identify new biocontrol strains, CHA0 would probably not have been carried forward to the next step in the screening process. A common approach to achieving better biocontrol is through the selection of new strains that are more suitable for controlling particular diseases or for use in particular environments. However, there are also incentives for improving the activity of an otherwise effective strain like CHA0.

Application of strain mixtures $(13,40)$ and genetic enhancement of antibiotic biosynthesis $(34,44)$ are two approaches that have been reported to improve the efficacy of CHA0 and other biocontrol strains. Taking a new approach, we investigated the use of mineral amendments as a way to create a more favorable environment for biocontrol to occur. This idea is based on the fact that certain diseases can be managed with mineral fertilization regimes. In most cases, the minerals work by directly reducing the inoculum

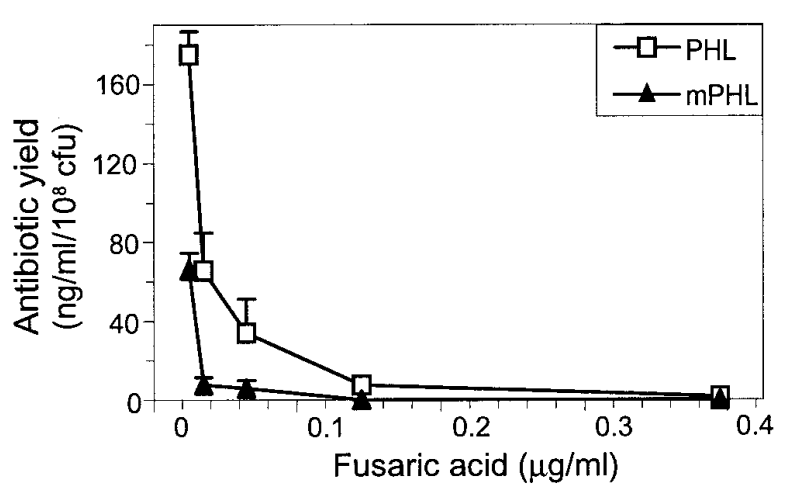

Fig. 4. Effect of fusaric acid on production of monoacetylphloroglucinol (mPHL) and 2,4-diacetylphloroglucinol (PHL) by Pseudomonas fluorescens biocontrol strain CHA0. CHA0 was grown for $48 \mathrm{~h}$ in PCG broth amended with synthetic fusaric acid (0 to $200 \mu \mathrm{g} / \mathrm{ml}$ ), and production of $\mathrm{mPHL}$ and PHL was quantified with high-performance liquid chromatography after ethylacetate extraction. At concentrations above $0.37 \mu \mathrm{g} / \mathrm{ml}$, no antibiotics were detected and data were not included in the analysis. Data were log-transformed prior to analysis. Values represent the mean (plus standard error of the mean) of six extractions per concentration. 
potential, improving host tolerance, or both $(16,42)$. For example, increasing the ratio of nitrate to ammonium forms of nitrogen reduces Fusarium wilt of tomato, because the nitrate-nitrogen raises soil $\mathrm{pH}$, reduces pathogen reproduction and propagule germination, and reduces the sensitivity of tomato to pathogen phytotoxins, particularly FA, while ammonium forms have the opposite effect $(5,19)$. Mandal and Sinha (23) suggested that zinc and other minerals reduce Fusarium wilt of tomato by inducing host resistance. There are a few cases, though, in which minerals appear to reduce disease by exerting an indirect beneficial effect on indigenous and introduced antagonistic microorganisms $(15,18)$. Zinc soil content has been found to be positively correlated with the biocontrol activity of introduced $P$. fluorescens 2-79 (44). Calcium has both a direct negative impact on the activity of postharvest pathogens of apple and citrus and an indirect positive impact on the biocontrol activity of saprophytic yeasts $(10,25)$.

We found that copper and zinc significantly improved the biocontrol activity of CHA0 against $F$. oxysporum $\mathrm{f}$. sp. radicis-lycopersici in soilless tomato culture. When used alone, copper reduced disease and improved plant growth, and it had an additive effect when used in combination with CHA0. In contrast, zinc had no direct effect on disease when used alone, indicating that it indirectly reduced disease through some influence on the interaction between the biocontrol agent and the pathogen. Initially, we thought that zinc improved biocontrol by stimulating the biosynthesis of bacterial antibiotics important in disease suppression. Zinc and other trace minerals stimulate the in vitro production of PHL, PLT, and phenazine-type antibiotics $(12,36)$ and stabilize regulatory genes critical for antibiotic production in fluorescent pseudomonads (11). However, the fact that zinc resulted in only a slight increase in the production of PHL in situ, from approximately 0.3 to $0.4 \mu \mathrm{g}$ per plant, and did not affect bacterial growth indicated the need for an alternate explanation.
Mineral nutrition is also important in the biology of the pathogen. We found that zinc and copper increased total biomass, increased conidiation, and altered the profile of secondary metabolites produced by $F$. oxysporum f. sp. radicis-lycopersici. The tomato crown and root rot pathogen produced FA, a pyridine-carboxylic acid (chemically, 5-butylpicolinic acid) with nonspecific phytotoxic activity that contributes to wilt and rot diseases of various crops caused by $F$. oxysporum $(7,21,32,39)$. FA production was completely repressed by zinc and copper at concentrations as low as $10 \mu \mathrm{g} / \mathrm{ml}$ and by a mineral mix with $3 \mu \mathrm{g} / \mathrm{ml}$ of each of these minerals. Ammonium-molybdate, which had no effect on disease or on biocontrol, also did not affect growth and FA production by $F$. oxysporum f. sp. radicis-lycopersici, even at a concentration of $100 \mu \mathrm{g} / \mathrm{ml}$. FA production was not detected in the tomato bioassay in two trials and detected at a low concentration $(0.7 \mu \mathrm{g}$ per plant $)$ in a third trial when plants were treated with zinc at $33 \mu \mathrm{g} / \mathrm{ml}$, but it was detected at $5.1 \mu \mathrm{g}$ per plant in the absence of zinc. Depending on concentration, zinc has been reported to increase $(3 \mu \mathrm{M})$ or decrease $(6 \mu \mathrm{M})$ FA production by the tomato wilt pathogen $F$. oxysporum $\mathrm{f}$. sp. lycopersici (14). FA production by nonpathogenic and moderately pathogenic strains tended to be more sensitive to zinc repression compared with production by highly pathogenic strains $(7,21)$. Zinc at concentrations of 15 to $150 \mu \mathrm{M}$ increased production of aflatoxin by Aspergillus parasiticus, but at concentrations of $150 \mu \mathrm{M}$ or more, toxin production was repressed (43). The fact that, in our experiment, disease severity was not reduced when FA production was repressed by zinc amendment does not preclude a role for this phytotoxin in disease development under other conditions. Rather, this suggests that $F$. oxysporum f. sp. radicis-lycopersici produces additional metabolites (e.g., other phytotoxins and lytic enzymes) that may have contributed to disease development. One or more of these pathogenicity factors may have

TABLE 1. Influence of fusaric acid (FA) and zinc on secondary metabolite production by Pseudomonas fluorescens strain CHA0

\begin{tabular}{|c|c|c|c|c|c|c|}
\hline \multirow[b]{2}{*}{ Amendment ${ }^{\mathrm{y}}$} & \multicolumn{4}{|c|}{ Yield (ng per ml per $\left.10^{8} \mathrm{CFU}\right)^{\mathrm{z}}$} & \multirow{2}{*}{$\begin{array}{c}\text { Protease }^{\mathrm{z}} \\
\text { (units per } 10^{8} \mathrm{CFU} \text { ) }\end{array}$} & \multirow[b]{2}{*}{$\mathrm{HCN}^{2}$} \\
\hline & PHL & PLT & SAL & $\mathrm{PCH}$ & & \\
\hline \multicolumn{7}{|c|}{ P. fluorescens $\mathrm{CHA0}$} \\
\hline None & $58.8 \pm 3.2$ & $15.6 \pm 4.0$ & $13.3 \pm 1.2$ & $819.6 \pm 74.2$ & $10.9 \pm 0.5$ & + \\
\hline FA & $<0.01$ & $8.3 \pm 1.3$ & $24.9 \pm 2.5$ & $513.1 \pm 61.1$ & $9.8 \pm 0.3$ & + \\
\hline FA plus zinc & $<0.01$ & $9.2 \pm 1.7$ & $22.7 \pm 1.4$ & $520.4 \pm 138.9$ & nd & + \\
\hline Zinc & $87.8 \pm 6.2$ & $32.7 \pm 10.4$ & $18.3 \pm 4.5$ & $962.6 \pm 297.9$ & nd & + \\
\hline \multicolumn{7}{|c|}{ P. fluorescens CHA0/pME3424 } \\
\hline None & $303.9 \pm 14.3$ & nd & nd & nd & nd & + \\
\hline FA & $<0.01$ & nd & nd & nd & nd & + \\
\hline
\end{tabular}

y Autoclaved media was amended with FA to give $100 \mu \mathrm{g} / \mathrm{ml}$ and with $\mathrm{ZnSO}_{4} \cdot 7 \mathrm{H}_{2} \mathrm{O}$ at $66 \mu \mathrm{g}$ of $\mathrm{Zn}^{2+} / \mathrm{ml}$.

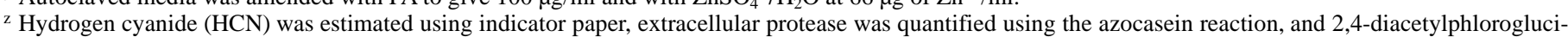
nol (PHL), pyoluteorin (PLT), salicylic acid (SAL), and pyochelin (PCH) were quantified using high-performance liquid chromatography analysis. Protease and PLT were determined in GNB medium. Other metabolites were determined in PCG medium. Values represent the mean of six replicate broth cultures $( \pm$ standard error of the mean). nd = not determined.

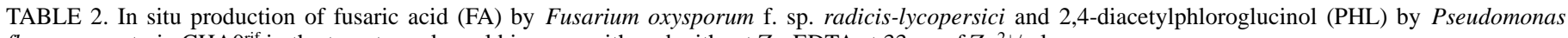
fluorescens strain CHA0 ${ }^{\text {rif }}$ in the tomato rockwool bioassay with and without $\mathrm{Zn}-\mathrm{EDTA}$ at $33 \mu \mathrm{g}$ of $\mathrm{Zn}^{2+} / \mathrm{ml}^{2}$

\begin{tabular}{|c|c|c|c|c|c|}
\hline Microorganisms added & Zn-EDTA & $\begin{array}{c}\text { PHL } \\
(\mu \mathrm{g} \text { per plant })^{\mathrm{x}, \mathrm{y}}\end{array}$ & $\begin{array}{c}\text { FA } \\
(\mu \mathrm{g} \text { per plant })^{\mathrm{x}, \mathrm{y}}\end{array}$ & $\begin{array}{c}\text { CHA0 } 0^{\text {rif }} \\
\left(10^{5} \mathrm{CFU}_{\text {per } \mathrm{ml}}\right)^{\mathrm{y}, \mathrm{z}}\end{array}$ & $\begin{array}{l}\text { F. oxysporum f. sp. radicis-lycopersici } \\
\qquad\left(10^{4} \mathrm{CFU} \text { per } \mathrm{ml}\right)^{\mathrm{y}, \mathrm{z}}\end{array}$ \\
\hline \multirow[t]{2}{*}{ None } & - & $<0.07$ & $<0.45$ & 0 & 0 \\
\hline & + & $<0.07$ & $<0.45$ & 0 & 0 \\
\hline \multicolumn{6}{|c|}{ F. oxysporum f. sp. radicis-lycopersici } \\
\hline \multirow[t]{2}{*}{ alone } & - & $<0.07$ & $5.1(2.5 \text { to } 7.4)^{*}$ & 0 & $10.9 \pm 2.3$ \\
\hline & + & $<0.07$ & $0.4(0$ to 0.71$)$ & 0 & $9.1 \pm 1.7$ \\
\hline \multirow[t]{2}{*}{$\mathrm{CHA0}^{\text {rif }}$ alone } & - & $0.29(0.11$ to 0.41$)$ & $<0.45$ & $7.9 \pm 1.9$ & 0 \\
\hline & + & $0.39(0.12$ to 0.65$)$ & $<0.45$ & $6.3 \pm 2.1$ & 0 \\
\hline \multicolumn{6}{|c|}{ F. oxysporum f. sp. radicis-lycopersici } \\
\hline \multirow[t]{2}{*}{ plus CHA0 ${ }^{\text {rif }}$} & - & $<0.07$ & $5.7(2.3 \text { to } 7.9)^{*}$ & $5.5 \pm 0.6$ & $9.7 \pm 1.9 *$ \\
\hline & + & $0.48(0.26 \text { to } 0.66)^{*}$ & $<0.45$ & $9.5 \pm 2.9 *$ & $5.6 \pm 1.8$ \\
\hline
\end{tabular}

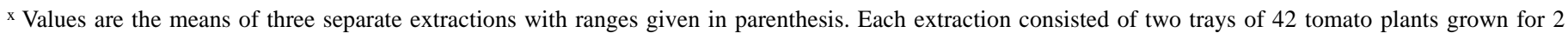
weeks in rockwool. Detection limits for PHL and FA were approximately 0.07 and $0.45 \mu \mathrm{g}$ per plant, respectively.

y Within a microbial treatment, * indicates that means for plus and minus zinc were significantly different according to Student's $t$ test $(P \leq 0.04)$.

${ }^{\mathrm{z}}$ Microbial numbers are the means for three trials with \pm standard error of the means. 
been insensitive to repression by zinc or may even have been stimulated by zinc.

Zinc clearly had an effect on FA production by the pathogen and on antibiotic production by the biocontrol agent. However, neither interaction alone seemed to explain the influence of zinc on biocontrol. A simple experiment intended to show that CHA0 did not degrade FA unexpectedly revealed that FA at concentrations as low as $0.1 \mu \mathrm{g} / \mathrm{ml}$ repressed production of PHL by the biocontrol agent. This suggested that zinc may indirectly improve biocontrol by removing FA from the system, thereby creating an environment more conducive for the production of PHL by CHA0. Indeed, when microbial metabolite production was measured in the tomato bioassay, zinc repression of FA production in situ was accompanied by increased production of PHL by CHAO in situ. This is perhaps the first evidence that pathogens can have a direct impact on the mechanism(s) of action of biocontrol agents. Previously, fungal pathogens have been shown to have a selective influence, positive and negative, on the proliferation of bacterial biocontrol agents in the rhizosphere of wheat (24) and to influence bacterial chemotaxis (2).

The mechanism by which FA represses antibiotic production by CHA0 is uncertain. FA is toxic to animal, plant, fungal, and bacterial cells primarily because it interferes with cell function (e.g., respiration, membrane integrity, adenosine triphosphate levels, and enzyme activity) $(17,21,30,31)$. However, growth of CHA0 was not reduced by FA even at concentrations well above that needed for repression of antibiotic production. The $\mathrm{pH}$ of the medium, which is important in antibiotic biosynthesis $(12,37)$, was also not affected by FA. FA did not interfere with the recovery of preformed antibiotic, a further indication that some step in the biosynthetic pathway was interrupted. Production of hydrogen cyanide and extracellular protease was not repressed, suggesting that the target site for FA is downstream from the global regulatory genes gacA and apdA, perhaps at the promoter or transcription level of the polyketide antibiotics PHL and PLT. Competition with enzymes involved in the biosynthesis of these antibiotics may also play a role $(9,21,29,31)$, but this would have to be highly specific considering that a small amount of FA is sufficient to inhibit antibiotic production even by an antibiotic-overproducing derivative of $\mathrm{CHA} 0$.

Chelation of minerals by FA contributes to its general toxicity and also to its antidepressant activity in mammals $(6,21)$. It is difficult to confirm if mineral chelation may play a role in repression of bacterial antibiotic biosynthesis, because such chelation would also affect FA availability, thereby precluding observation of possible specific interactions with the bacteria (21). While zinc amendments did not relieve FA-mediated antibiotic repression, repression may have resulted from chelation of iron or other minerals that directly or indirectly influence antibiotic biosynthesis and for which FA has a higher affinity. However, the fact that hydrogen cyanide, which is sensitive to iron availability (40), was not repressed by FA and that antibiotic production was not affected by the high-affinity iron chelator EDDHA (B. Duffy, unpublished data) suggests that chelation was not the only factor in FA-mediated repression of antibiotic production by CHA0.

Trace mineral amendments are an inexpensive way to improve the biocontrol activity of certain bacterial strains. Formulations that efficiently supply minerals to the target strain may further improve their availability and effect on biocontrol, which means lower doses and reduced costs. Formulations that more selectively provide minerals to the biocontrol strain should also limit potential nontarget toxicity to other beneficial microorganisms $(3,28)$ and avoid increases in pathogenic activity (19). Identification of mineral amendments that favor biocontrol may also provide clues to soil factors or components of nutrient solutions in hydroponic culture that will improve the level and reliability of biocontrol. Zinc amendments improved the biocontrol activity of $P$. fluorescens 2-79, and the variable performance of this strain in the field was associated with soil concentrations of zinc (44). Identification of the fungal pathogenicity factor, FA, as deleterious to the bio- control activity of CHA0 may explain, in part, the moderate performance of this strain against Fusarium crown and root rot of tomato. FA is produced by a wide range of plant-associated fusaria $(1,4)$ and it may have an influence on biocontrol in other pathosystems. When faced with FA-producing pathogens, better disease control might be achieved by using biocontrol strains insensitive to FA-mediated antibiotic inhibition or by using strains capable of degrading FA (39).

\section{ACKNOWLEDGMENTS}

This work was supported by the Swiss Federal Institute of Technology and the Swiss National Science Foundation (grant 3100-50522.97). We thank S. Berdat for technical support, and M. Finckh, M. Maurhofer, and M. Wolfe for critical review of the manuscript prior to submission. We also thank U. Burger, Department of Organic Chemistry, University of Geneva, for providing synthetic standards of 2,4-diacetylphloroglucinol and pyoluteorin.

\section{LITERATURE CITED}

1. Abbas, H. K., Mirocha, C. J., Kommedahl, T., Vesonder, R. F., and Golinski, P. 1989. Production of trichothecene and non-trichothecene mycotoxins by Fusarium species isolated from maize in Minnesota (USA). Mycopathologia 108:55-58.

2. Arora, D. K. 1986. Chemotaxis of Actinoplanes missouriensis zoospores to fungal conidia, chlamydospores and sclerotia. J. Gen. Microbiol. 132: 1657-1664.

3. Babich, H., and Stotzky, G. 1978. Toxicity of zinc to fungi, bacteria, and coliphages: Influence of chloride ions. Appl. Environ. Microbiol. 36:906-914.

4. Bacon, C. W., Porter, J. K., Norred, W. P., and Leslie, J. F. 1996. Production of fusaric acid by Fusarium species. Appl. Environ. Microbiol. 62: 4039-4043.

5. Barna, B., Sarhan, A. R. T., and Király, Z. 1983. The influence of nitrogen nutrition on the sensitivity of tomato plants to culture filtrates of Fusarium and to fusaric acid. Physiol. Plant Pathol. 23:257-263.

6. Bochner, B. R., Huang, H.-C., Schieven, G. L., and Ames, B. N. 1980. Positive selection of tetracycline resistance. J. Bacteriol. 143:926-933.

7. Chakrabarti, D. K., and Basu Chaudhary, K. C. 1980. Correlation between virulence and fusaric acid production in Fusarium oxysporum f.sp. carthami. J. Phytopathol. 99:43-46.

8. Cook, R. J. 1993. Making greater use of introduced microorganisms for biological control of plant pathogens. Annu. Rev. Phytopathol. 31:53-80.

9. Diringer, M. N., Kramarcy, N. R., Brown, J. W., and Thurmond, J. B. 1982. Effect of fusaric acid on aggression, motor activity and brain monoamines, in mice. Pharmacol. Biochem. Behav. 16:73-80.

10. Droby, S., Wisniewski, M. E., Cohen, L., Weiss, B., Touitou, D., Eilam, Y., and Chalutz, E. 1997. Influence of $\mathrm{CaCl}_{2}$ on Penicillium digitatum, grapefruit peel tissue, and biocontrol activity of Pichia guilliermondii. Phytopathology 87:310-315.

11. Duffy, B. K., and Défago, G. 1995. Influence of cultural conditions on spontaneous mutations in Pseudomonas fluorescens CHA0. (Abstr.) Phytopathology 85:1146.

12. Duffy, B. K., and Défago, G. 1996. Influence of minerals, C-source, and $\mathrm{pH}$ on antibiotic and salicylate production by Pseudomonas fluorescens biocontrol strain CHA0. (Abstr.) Phytopathology 86(suppl.):S79.

13. Duffy, B. K., Simon, A., and Weller, D. M. 1996. Combination of Trichoderma koningii with fluorescent pseudomonads for control of take-all on wheat. Phytopathology 86:188-194.

14. Egli, T. A. 1969. Untersuchungen über den Einfluss von Schwermetallen auf Fusarium lycopersici Sacc. und den Krankheitsverlauf der tomatenwelke. J. Phytopathol. 66:223-252.

15. Elmer, W. H. 1995. Association between Mn-reducing root bacteria and $\mathrm{NaCl}$ applications in suppression of Fusarium crown and root rot of asparagus. Phytopathology 85:1461-1467.

16. Engelhard, A. W. 1989. Soilborne Plant Pathogens: Management of Diseases with Macro- and Microelements. The American Phytopathological Society, St. Paul, MN.

17. Fernandez-Pol, J. A., Klos, D. J., and Hamilton, P. D. 1993. Cytotoxic activity of fusaric acid on human adenocarcinoma cells in tissue culture. Anticancer Res. 13:57-64.

18. Huber, D. M. 1989. The role of nutrition in the take-all disease of wheat and other small grains. Pages 46-74 in: Soilborne Plant Pathogens: Management of Diseases with Macro- and Microelements. A. W. Engelhard, ed. The American Phytopathological Society, St. Paul, MN.

19. Jones, J. P., Engelhard, A. W., and Woltz, S. S. 1989. Management of Fusarium wilt of vegetables and ornamentals by macro- and microele- 
ment nutrition. Pages 18-32 in: Soilborne Plant Pathogens: Management of Diseases with Macro- and Microelements. A. W. Engelhard, ed. The American Phytopathological Society, St. Paul, MN.

20. Keel, C., Schnider, U., Maurhofer, M., Voisard, C., Laville, J., Burger, U., Wirthner, P., Haas, D., and Défago, G. 1992. Suppression of root diseases by Pseudomonas fluorescens CHA0: Importance of the bacterial secondary metabolite 2,4-diacetylphloroglucinol. Mol. Plant-Microbe Interact. 5:4-13.

21. Kern, H. 1972. Phytotoxins produced by fusaria. Pages 35-44 in: Phytotoxins in Plant Diseases. R. K. S. Wood, A. Ballio, and A. Graniti, eds. Academic Press, New York.

22. Komada, H. 1975. Development of a selective medium for quantitative isolation of Fusarium oxysporum from natural soils. Rev. Plant Prot. Res. 8:114-125.

23. Mandal, N. C., and Sinha, A. K. 1992. An alternative approach for the chemical control of Fusarium wilt of tomato. Indian Phytopathol. 45: 194-198.

24. Mazzola, M., and Cook, R. J. 1991. Effects of fungal root pathogens on the population dynamics of biocontrol strains of fluorescent pseudomonads in the wheat rhizosphere. Appl. Environ. Microbiol. 57:2171-2178.

25. McLaughlin, R. J., Wisniewski, M. E., Wilson, C. L., and Chalutz, E. 1990. Effect of inoculum concentration and salt solutions on biological control of postharvest diseases of apple with Candida sp. Phytopathology 80:456-461.

26. Mihuta-Grimm, L., Erb, W. A., and Rowe, R. C. 1990. Fusarium crown and root rot of tomato in greenhouse rock wool systems: Sources of inoculum and disease management with benomyl. Plant Dis. 74:996-1002.

27. Ownley, B. H., Weller, D. M., and Thomashow, L. S. 1992. Influence of in situ and in vitro $\mathrm{pH}$ on suppression of Gaeumannomyces graminis var. tritici by Pseudomonas fluorescens 2-79. Phytopathology 82:178-184.

28. Page, W. J., Manchak, J., and Yohemas, M. 1996. Inhibition of Azotobacter salinestris growth by zinc under iron-limited conditions. Can. J. Microbiol. 42:655-661.

29. Pandy, R. S., Sreenivas, K. N., Patil, N. M., and Swamy, H. S. 1981. Dopamine beta-hydroxylase inhibition in a patient with Wilsons disease and manic symptoms. Am. J. Psychiatry 138:1628-1629.

30. Porter, J. K., Wray, E. M., Rimando, A. M., Stancel, P. C., Bacon, C. W., and Voss, K. A. 1996. Lactational passage of fusaric acid from the feed of nursing dams to the neonate rat and effects on pineal neurochemistry in the F1 and F2 generations at weaning. J. Toxicol. Environ. Health 49:161-175.

31. Prabhakaran, K., Harris, E. B., Tsutsumi, S., and Kirchheimer, W. F. 1983. Effect of fusaric acid on $o$-diphenoloxidase and on multiplication of Mycobacterium leprae. Microbios Lett. 22:81-84.

32. Remotti, P. C., and Löffler, H. J. M. 1996. The involvement of fusaric acid in the bulb-rot of gladiolus. J. Phytopathol. 144:405-411.

33. Sacherer, P., Défago, G., and Haas, D. 1994. Extracellular protease and phospholipase $\mathrm{C}$ are controlled by the global regulatory gene gacA in the biocontrol strain Pseudomonas fluorescens CHA0. FEMS (Fed. Eur. Microbiol. Soc.) Microbiol. Lett. 16:155-160.

34. Schnider, U., Keel, C., Blumer, C., Troxler, J., Défago, G., and Haas, D. 1995. Amplification of the housekeeping sigma factor in Pseudomonas fluorescens $\mathrm{CHA} 0$ enhances antibiotic production and improves biocontrol abilities. J. Bacteriol. 177:5387-5392.

35. Simon, A., and Sivasithamparam, K. 1989. Pathogen-suppression: A case study in biological suppression of Gaeumannomyces graminis var. tritici in soil. Soil. Biol. Biochem. 21:331-337.

36. Slininger, P. J., and Jackson, M. A. 1992. Nutritional factors regulating growth and accumulation of phenazine 1-carboxylic acid by Pseudomonas fluorescens 2-79. Appl. Microbiol. Biotechnol. 37:388-392.

37. Slininger, P. J., and Shea-Wilbur, M. A. 1995. Liquid-culture pH, temperature, and carbon (not nitrogen) source regulate phenazine productivity of the take-all biocontrol agent Pseudomonas fluorescens 2-79. Appl. Microbiol. Biotechnol. 43:794-800.

38. Taylor, A. G., and Harman, G. E. 1990. Concepts and technologies of selected seed treatments. Annu. Rev. Phytopathol. 28:321-339.

39. Toyoda, H., Hashimoto, H., Utsumi, R., Kobayashi, H., and Ouchi, S. 1988. Detoxification of fusaric acid by a fusaric acid-resistant mutant of Pseudomonas solanacearum and its application to biological control of Fusarium wilt of tomato. Phytopathology 78:1307-1311.

40. Voisard, C., Bull, C. T., Keel, C., Laville, J., Maurhofer, M., Schnider, U., Défago, G., and Haas, D. 1994. Biocontrol of root diseases by Pseudomonas fluorescens CHA0: Current concepts and experimental approaches. Pages 67-89 in: Molecular Ecology of Rhizosphere Microorganisms: Biotechnology and the Release of GMO's. F. O'Gara, D. N. Dowling, and B. Boesten, eds. VCH, Weinheim, Germany.

41. Voisard, C., Keel, C., Haas, D., and Défago, G. 1989. Cyanide production by Pseudomonas fluorescens helps suppress black root rot of tobacco under gnotobiotic conditions. EMBO (Eur. Mol. Biol. Organ.) J. 8:351-358.

42. von Broembsen, S. L., and Deacon, J. W. 1997. Calcium interference with zoospore biology and infectivity of Phytophthora parasitica in nutrient irrigation solutions. Phytopathology 87:522-528.

43. Weinberg, E. D. 1977. Mineral element control of microbial secondary metabolism. Pages 289-316 in: Microorganisms and Minerals. E. D. Weinberg, ed. Marcel Dekker, New York.

44. Weller, D. M., and Thomashow, L. S. 1994. Current challenges in introducing beneficial microorganisms into the rhizosphere. Pages 1-18 in: Molecular Ecology of Rhizosphere Microorganisms: Biotechnology and the Release of GMO's. F. O'Gara, D. N. Dowling, and B. Boesten, eds. VCH, Weinheim, Germany. 